
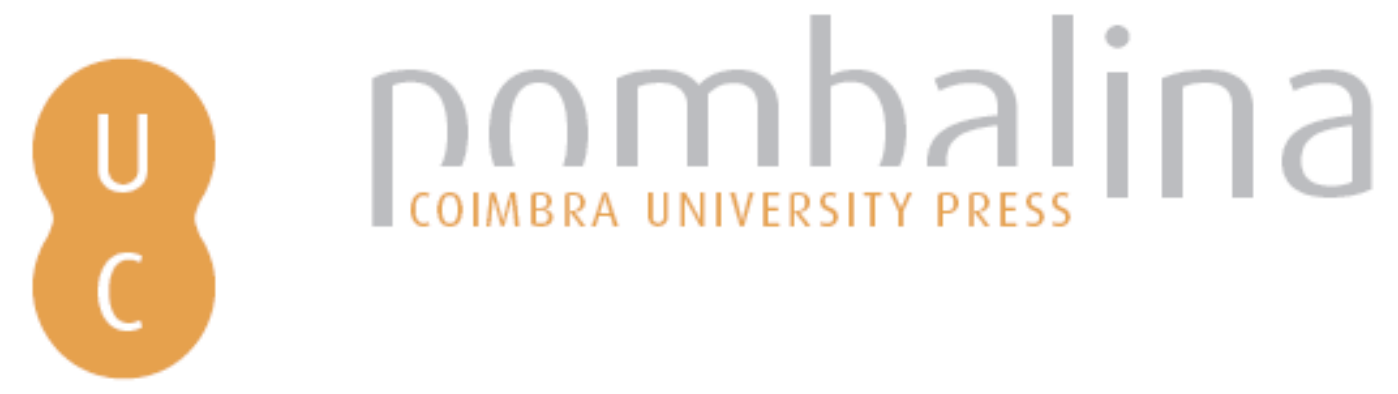

\title{
Merleau-Ponty e Paul Ricoeur: aspetos de uma concordância discordante sobre a fenomenologia da linguagem
}

\author{
Autor(es): $\quad$ Portocarrero, Maria Luísa \\ Publicado por: Imprensa da Universidade de Coimbra \\ URL \\ persistente: URI:http://hdl.handle.net/10316.2/38249 \\ DOI: $\quad$ DOl:http://dx.doi.org/10.14195/978-989-26-1049-8_13 \\ Accessed : $\quad$ 26-Apr-2023 13:37:50
}

A navegação consulta e descarregamento dos títulos inseridos nas Bibliotecas Digitais UC Digitalis, UC Pombalina e UC Impactum, pressupõem a aceitação plena e sem reservas dos Termos e Condições de Uso destas Bibliotecas Digitais, disponíveis em https://digitalis.uc.pt/pt-pt/termos.

Conforme exposto nos referidos Termos e Condições de Uso, o descarregamento de títulos de acesso restrito requer uma licença válida de autorização devendo o utilizador aceder ao(s) documento(s) a partir de um endereço de IP da instituição detentora da supramencionada licença.

Ao utilizador é apenas permitido o descarregamento para uso pessoal, pelo que o emprego do(s) título(s) descarregado(s) para outro fim, designadamente comercial, carece de autorização do respetivo autor ou editor da obra.

Na medida em que todas as obras da UC Digitalis se encontram protegidas pelo Código do Direito de Autor e Direitos Conexos e demais legislação aplicável, toda a cópia, parcial ou total, deste documento, nos casos em que é legalmente admitida, deverá conter ou fazer-se acompanhar por este aviso.

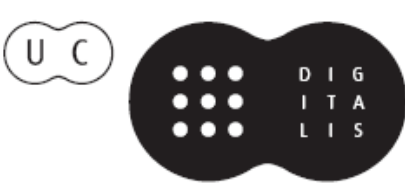



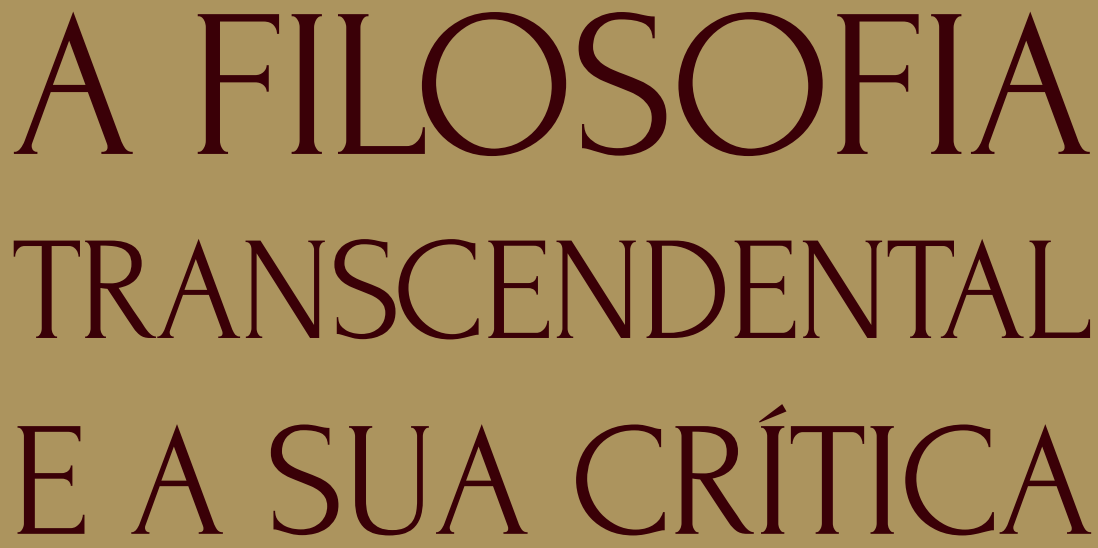

IDEALISMO • FenOMENOLOGIA • HERMENÊUTICA

\author{
DIOGO FERRER \\ LUCIANO UTTEICH \\ (COORDENADORES)
}




\title{
MERLEAU-PONTY E PAUL RICOEUR: ASPETOS DE UMA CONCORDÂNCIA DISCORDANTE

\author{
MERLEAU-PONTY AND PAUL RICOEUR: ASPECTS OF A \\ DISCORDANT AGREEMENT
}

Maria Luísa Portocarrero*

(Universidade de Coimbra)

\begin{abstract}
This Chapter deals with the critical relationship that Ricoeur sets with Merleau-Ponty's Phenomenology. Ricouer considers it still closely linked to the problem of perception, namely insofar as it adheres to a narrow conception of language and meaning. Ricoeur's Hermeneutic Phenomenology proposes to think the problem of praxis in dialogue with the sciences of language and taking very seriously the issue of the production of symbolic, metaphorical and narrative text. This is the true significance core of the phenomenological reduction.
\end{abstract}

Keywords: Phenomenology of perception, hermeneutic phenomenology, meaning, symbol, metaphor, narrative.

\footnotetext{
${ }^{*}$ Professora catedrática na Universidade de Coimbra . Tem como áreas de interesse a Fenomenologia, a Hermenêutica Filosófica e a Ética e Bioética .

Full professor at the University of Coimbra. His areas of interest: Phenomenology, Hermeneutics and Philosophical Ethics and Bioethics.

mlp600@gmail.com
} 
Resumo: Este capítulo aborda a relação crítica que Ricoeur estabelece com fenomenologia de M. Ponty que considera ainda muito ligada ao problema da perceção e, nomeadamente, detentora de uma conceção de linguagem e de significação limitada. A fenomenologia hermenêutica de Ricoeur propõe-se pensar o problema da praxis, dialogando com as ciências da linguagem e levando muito a sério a produção do texto simbólico, metafórico e narrativo como verdadeiro núcleo do alcance da redução fenomenológica.

Palavras-Chave: Fenomenologia da perceção, fenomenologia hermenêutica, significação, símbolo, metáfora, narrativa

O movimento fenomenológico do início do século XX é partilhado por Merleau-Ponty e P. Ricoeur que o desenvolvem em contextos diferentes e de formas diversas. Dedicam-se os dois ao estudo da significação, emblema da fenomenologia, embora as suas conceções sobre a linguagem e a representação sejam distintas. Vamos dedicar-nos aos aspetos em que Ricoeur, quanto a este problema, critica e ultrapassa Merleau- Ponty, que considera ainda muito ligado, na linha de Husserl, ao problema do conhecimento.

O filósofo francês P. Ricoeur conhece Merleau-Ponty e a obra Fenomenologia da Percepção ${ }^{766}$ exatamente na altura em que escreve a sua tese sobre o Voluntário e o Involuntário e em que acaba a tradução das Ideen de Husserl. Valoriza claramente, nesta obra, a preocupação que partilha de evitar as dicotomias estéreis dos racionalistas, nomeadamente, sobre o sujeito e o objeto. A este tipo de posições Merleau-Ponty opunha uma análise concreta da experiência humana e uma filosofia

766 M. Merleau Ponty (1945). 
que tentava sobretudo pensar as significações que permitem "colocar a consciência em presença da sua vida refletida nas coisas". Recusando as posições tradicionais do realismo e do idealismo, o filósofo orientava-nos para o espaço originário e nada explorado, até então, do corpo vivido, o tecido básico em que se inscrevem em simultâneo a consciência e o mundo. Mostrava-nos assim como é que todo o campo percetivo se organiza sempre a partir do nosso corpo próprio, isto é, do fundo silencioso sempre presente nas nossas palavras, atos e gestos.

O que mais impressiona Ricoeur nesta fenomenologia do corpo próprio é o modo como, para além da perceção das formas, o sentir ligado ao corpo é valorizado como forma de comunicação vital com o mundo e torna este presente enquanto lugar familiar da nossa própria vida. A reestruturação conceptual de tipo antropológico que esta tese implica, nomeadamente, quanto ao primado do Cogito, interessa especialmente a Ricoeur. O filósofo, na sua obra O Homem Falível ${ }^{767}$, devotada à problemática da desproporção humana, elabora justamente uma filosofia do sentimento com o intuito de revelar, contra a tradição da filosofia reflexiva, de linha cartesiana, a génese mútua do sentir e do conhecer, o movimento de mútua promoção do sentimento e da razão que assim se explicam um pelo outro e não um contra o outro: "por um lado o poder de conhecer, ao hierarquizar-se, gera verdadeiramente os graus do sentimento e arranca este último à sua essencial confusão; por outro, o sentimento gera realmente a intenção do conhecer a todos os níveis. É nesta génese mútua que a unidade do sentir (...) se constitui."768

Esta tese que, como dissemos, Ricoeur partilha com Merleau-Ponty, implica toda uma assunção da passividade do corpo próprio que exige que se passe filosoficamente do eu penso ao eu posso (tomar posse de $\mathrm{mim})$, intuito que será claramente o de Ricoeur, nomeadamente quando alarga a sua Fenomenologia do campo da perceção ao âmbito da praxis.

\footnotetext{
767 Ricoeur (1960).

768 Ricoeur (1960), 99.
} 
Mas vamos dedicar-nos mais particularmente como dissemos à atenção que Ricoeur dedica ao problema da comunicação em Merleau-Ponty, questão que lhe merece uma análise aprofundada, indicando mesmo ao autor de Signes ${ }^{769}$ os seus próprios limites na exploração de uma fenomenologia da linguagem. A questão da linguagem é uma questão crucial em Ricoeur que, pretendendo desenvolver as potencialidades do cogito concreto, isto é, do corpo próprio de Merleau-Ponty, sabe que é no mundo da interação que elas melhor se manifestam e expressam por meio da linguagem, como já o revelava Aristóteles na Poética e mais tarde algumas dimensões das filosofias analíticas.

Digamos então para começar que Ricoeur presta uma séria homenagem a Merleau-Ponty, mas se distancia do seu projeto fenomenológico. Daí o nosso título: uma concordância discordante. Ouçamos então o que nos diz o filósofo ainda antes de analisarmos as questões suscitadas por Signes:

"Pensei no início escrever uma obra sobre a vontade a que dei o nome A Filosofia da Vontade e que equivaleria - era um projeto audacioso - à Fenomenologia da Perceção. A origem deste projeto era a minha grande admiração por Merleau-Ponty e também a surpresa por ver que a Fenomenologia estava inteiramente dominada pelo problema da perceção. Fiquei sensibilizado ao ver que a Fenomenologia permanecia neste sentido ligada a uma linha platónica da visão e a uma linha kantiana da objetividade. Assim o domínio do agir, a prática, parecia-me filosoficamente em aberto."770

Pensar a praxis no sentido da grande tradição (da praxis) da filosofia de Aristóteles, pensar o âmbito da praxis individual e coletiva que desemboca numa ética e numa política, tal é pois o caminho novo

\footnotetext{
769 Merleau-Ponty (1960).

770 Ricoeur, Carlos Oliveira (1990), 17.
} 
que vai iniciar P. Ricoeur, trilha que o vai levar a distanciar-se de Merleau-Ponty, apesar da grande admiração que lhe devota.

Vejamos então como tal acontece: a grande questão que vai nortear Ricoeur naquilo a que chamará a sua via longa de acesso ao homem da praxis, ao sujeito encarnado no mundo temporal das práticas vividas é justamente a do sentido deste novo sujeito. O Voluntário e o Involuntário e as obras, Finitude e Culpabilidade e A Simbólica do Mal ${ }^{771}$, mostravam justamente que é preciso fazer uma hermenêutica do eu sou, descobrir o homem concreto, mas não desconstruir pura e simplesmente o sujeito, como algumas correntes de pensamento dos anos sessenta, de índole semiológica, iam proclamando. É neste sentido que Merleau-Ponty é ainda para Ricoeur importante: como fenomenólogo, ele não desiste do sujeito e sabe articular uma filosofia do sujeito com uma teoria da significação que entra no mesmo campo epistemológico que o dos modelos semiológicos de crítica do sujeito. M. Ponty partilha as grandes teses da Fenomenologia husserliana, nomeadamente: a) a da significação como a categoria mais envolvente da descrição fenomenológica ${ }^{772 ;}$ b) a do sujeito enquanto portador da significação; c) a da redução como o ato filosófico que é condição do nascimento de um ser para a significação ${ }^{773}$. Merleau-Ponty sabe também sublinhar que, pela sua descoberta da significação como mediação universal entre o sujeito e o mundo, a Fenomenologia pode ser considerada como uma teoria da linguagem. Tal é a tese de fundo de Signes. Nesta obra, a linguagem identifica-se com o meio significante total, isto é, com a rede de signos que constitui a teia que envolve o nosso campo de perceção, de ação e da vida. Ricoeur concorda plenamente com Merleau-Ponty quando este afirma que Husserl elevou a linguagem a problema central da filosofia. De facto, ao descobrir pela primeira vez a atitude intencional e significante do sujeito encarnado,

\footnotetext{
771 Ricoeur (1960b).

772 Ricoeur (1969), 242.

773 Ricoeur (1969), 242.
} 
que percebe, que age e que fala, a Fenomenologia descobriu em toda a envergadura o espaço da significação e da linguagem. No entanto, ela limitou-lhe o alcance ao fechar-se ao diálogo com as ciências humanas, nomeadamente com as da linguagem.

Ora, pensar a praxis exige um diálogo sério com estas ciências e é justamente neste aspeto que Ricoeur sente necessidade de ir mais longe, contestando a oposição que Merleau-Ponty estabelece, na linha do último Husserl, entre a atitude fenomenológica e a objetiva. Com esta posição, Merleau-Ponty concebe o retorno ao sujeito falante de forma demasiado apressada, isto é, dirige-se de uma forma ingénua e não crítica para a dimensão semântica da linguagem, em ordem a trabalhar a sua fenomenologia da palavra.

Ora, lembra Ricoeur, quando se pretende retomar num sentido não psicologista, nem solipsista as noções de intencionalidade, de visada e de expressão não se pode esquecer a língua e os seus códigos pois só ela permite a uma fenomenologia da palavra escapar ao psicologismo ou mesmo a uma compreensão formada no prolongamento direto da ideia de gesto. Mas, é esta a atitude de Signes: porque Merleau-Ponty considera que a linguística cai no âmbito do objetivismo e porque vê a linguagem no passado, Signes coloca a sincronia do lado do sujeito que fala - é na atualidade da palavra que um sistema se institui - e a diacronia do lado objetivo da ciência. Envolve assim o ponto de vista objetivo no subjetivo e todo o seu escopo é revelar como é que a linguagem passada habita a presente, des-subjetivando deste modo a consciência.

A palavra reanima, segundo Merleau-Ponty, um certo saber linguístico que vem da tradição e que por isso constitui uma sedimentação que permite, por sua vez, a quem vai falar dar uma carne a este vazio que preenche em mim a intenção significativa. A palavra é, como diz Ricoeur, aqui assimilada assim a um mero gesto que põe em ato um saber fazer, um poder adquirido. Total e radicalmente de fora fica toda a inscrição do sujeito que fala num sistema de regras comuns, o mundo objetivo dos signos, um transcendental sem sujeito, isto é, a língua como 
estrutura inconsciente que ultrapassa todo o factualismo e psicologismo e é, segundo Ricoeur, um verdadeiro resultado da capacidade humana de redução. Merleau-Ponty não pôde pois perceber o grande desafio que a linguística estrutural impunha às filosofias do sujeito e que consistia justamente no facto de a noção de significação se constituir agora num âmbito muito diferente do das visadas intencionais do sujeito. Se a fenomenologia pressupõe a significação, como a sua categoria mais englobante, ela radicalizou, nomeadamente, com Merleau-Ponty "a questão da linguagem de uma maneira tal que não permitia um diálogo com a linguística moderna e com as ciências que se constituíram de acordo com o modelo linguístico. O exemplo de M.Ponty é, a este respeito, instrutivo pelo fracasso da sua filosofia da linguagem". ${ }^{774}$

O desvio necessário pela ciência dos signos, o diálogo com o estruturalismo, tal será de facto o grande desafio de P. Ricoeur. O filósofo pretende antes de mais trabalhar a distinção entre semiologia e semântica, para poder chegar finalmente a uma fenomenologia da palavra que lhe permita aceder à complexidade da praxis vivida dos homens. E só depois do desvio pela semântica narrativa da ação temporal é que voltará à questão do sujeito ou do quem da redução. Ricoeur recusa todo o acesso imediato ao sujeito. Este compreende-se a partir dos seus atos, textos e interpretações. Daí o valor da linguística e suas regras. O rodeio pela ciência dos signos obriga, de facto, a pôr entre parêntesis a questão tradicional do sujeito e leva ao adiamento de toda a referência direta ao sujeito falante. Será este o contexto em que Ricoeur se vai mover e assim já não nos falará em consciência, mas por fim em identidade narrativa e em si mesmo como um outro.

A grande questão de Ricoeur, na altura do diálogo com Signes, é então a seguinte: qual o tipo de filosofia do sujeito que poderemos pensar, depois do desafio do estruturalismo? Em que medida é que este pode, com as suas teses sobre a língua sem exterior e a sua distinção entre

774 Ricoeur (1969), 244. 
língua e palavra, contribuir para alargar o sentido originário da redução fenomenológica, enquanto suspensão do imediato? Para o filósofo só a passagem pela língua restitui à análise linguística da palavra o seu carácter objetivo, que é totalmente esquecido quando o procuramos num prolongamento direto da ideia de gesto. A ordem semiológica instituída por F. de Saussure no seu Curso de Linguística Geral representa o conjunto das condições de articulação dos signos entre si, signos sem os quais não existiria sequer um ato significativo da palavra. A hipótese do estruturalismo é esta: "é cientificamente legítimo descrever a linguagem como sendo essencialmente uma entidade autónoma com dependências internas, numa palavra, uma estrutura (Hjelmslev, Ensaios Linguísticos)."775

$\mathrm{Na}$ origem do estruturalismo sabemos que está o trabalho dos linguistas F. de Saussure, R. Jakobson, A. Martinet, que defenderam e realizaram uma importante inversão entre a perspetiva do sistema e a da história. O estruturalismo defendeu um modelo de compreensão a partir das organizações sistémicas, isto é, o primado do sistema e não o do sujeito no âmbito da linguagem. Sistema que se constitui pelas relações internas entre os seus elementos. É assim que procurando dar à linguística o estatuto de uma verdadeira ciência, Saussure operou no conjunto confuso da linguagem uma cisão entre Língua e Fala, fazendo da Língua o objeto da linguística científica. Para Saussure a língua não se confunde com a Linguagem, é a linguagem abstraída da palavra que, em sua opinião, pertence a vários registos: à física pela sua sonoridade, à fisiologia pelo prisma da sua articulação, à psicologia pela sua intenção, à sociologia pelo prisma da comunicação. Além disso, a palavra diz respeito simultaneamente ao âmbito social e ao individual. É pois algo que não se deixa reduzir a uma única espécie de factos humanos, enquanto pelo contrário, a Língua é algo de homogéneo, é o objeto de uma ciência única; é apenas uma convenção de natureza social ou é uma instituição que existe independentemente do seu uso.

775 Ricoeur (1969), 247. 
A língua é, em suma, o código de uma determinada comunidade linguística. Só é, de facto, possível falar de sistema se todos os elementos da língua são contemporâneos uns dos outros. O sistema requer o primado da sincronia. A Língua é então constituída por unidades (fonemas e morfemas) cujo número é finito mas que se prestam a inúmeras combinatórias. Ela é segundo Saussure uma espécie de tesouro colocado pela prática da palavra no inconsciente dos sujeitos que pertencem a uma mesma comunidade. É um transcendental sem sujeito; não está completa em nenhum indivíduo, apenas existe no seu conjunto, é exterior ao sujeito que sozinho não a pode nem criar nem modificar. Pelo contrário, a palavra é um ato individual de vontade e inteligência, no qual se distinguem as combinações por meio das quais o sujeito usa o código da língua para expressar o seu pensamento pessoal e o mecanismo psicofísico que lhe permite exteriorizar essas combinações.

Saussure exclui pois a palavra da ciência da linguagem, devido ao seu carácter heterogéneo ela é: individual e imprevisível. O objetivo de Saussure é poder chegar à Língua, enquanto linguagem na totalidade das suas formas observáveis e constantes. O Curso de Linguística Geral propõe assim que se parta da expressão linguística nativa para decompor cada enunciado nos seus elementos e estes ainda até se chegar aos seus elementos mínimos. Assim se encontram as unidades distintivas da Lingua tal como se conseguem estabelecer as leis que regulam e ordenam as várias combinatórias possíveis entre tais elementos. Os signos são as unidades mínimas da Língua e caracterizam-se por serem uma entidade que já não une um nome e uma coisa, porque a língua não é uma transposição de um real organizado e porque a relação entre a expressão e o mundo não interessa de todo ao linguista. Os signos apenas ligam um significante e um significado; o significante refere a cadeia sonora a ele associada e o significado a cadeia conceptual.

A mudança é grande e Merleau-Ponty não a aproveitou: de facto, se até Saussure o sinal linguístico era definido pela sua oposição e relação à coisa, se mantinha o vínculo com o mundo, agora o signo é definido 
pela relação de oposição de um conceito e de uma imagem acústica. Nesta definição do signo, como relação entre um significante e um significado, os dois termos estão do mesmo lado da rutura entre Língua e mundo. A significação do signo passa então a ser definida não pelo seu conteúdo intrínseco, mas pela sua relação de oposição relativamente a outros signos. Cada signo recebe a sua função do conjunto em que está inserido. É aliás este o princípio básico da noção de sistema e de estrutura: ele implica uma ordenação de um todo nas suas partes, tal como a solidariedade demonstrada entre as partes constitutivas do todo que, mutuamente, se condicionam. O que interessa a Saussure não são os elementos considerados individualmente, mas as diferenças de som e sentido e as múltiplas relações dos signos entre si. Ao linguista não importa a relação ao real, que é abandonada a outras esferas.

É certo que Ricoeur reconhece que a fenomenologia da palavra de Merleau- Ponty dava corpo às grandes questões que o Estruturalismo esquecia e às quais não dava resposta, nomeadamente a pergunta sobre como é que o sistema pode existir e evoluir para novos equilíbrios dispensando o ato da palavra. No entanto, e será este o desafio de Ricoeur: responder a estas questões implica passar pelo Estruturalismo, como condição de alargamento da redução fenomenológica à função simbólica da linguagem. É preciso dialogar com ele, em ordem a acrescentar-lhe o que ele pressupõe e, no entanto, esquece: tal será precisamente a tarefa da compreensão hermenêutica. O estruturalismo pode ajudar a ultrapassar a atitude naturalista relativamente à linguagem e a reinterpretar o alcance da redução fenomenológica; mas é claro que a ordem semiológica não chega sozinha, com os seus pressupostos imanentistas, para pensar a linguagem. Esta não existe, segundo Ricoeur, apenas para sua própria glória; “[...] a ordem semiológica não constitui o todo da linguagem, é ainda preciso passar da língua ao discurso; é apenas a este nível que se pode falar de significação."776

776 Ricoeur (1969), 256. 
Como aliás observa a psicanálise, que Ricoeur analisa também na sua exploração do significado do símbolo, uma sintaxe de arranjos não se sobrepõe nunca a uma semântica de conteúdos. Então uma fenomenologia hermenêutica da linguagem deve dialogar criticamente com os pressupostos da semiologia, tendo claramente em vista a reconquista da relação de transcendência própria da redução fenomenológica; “[...] o discurso é uma coisa diferente da língua e a significação outra coisa distinta do signo. Por conseguinte, a reflexão que se limitasse a explicitar as condições da ordem semiológica falharia muito simplesmente o problema das condições de possibilidade da ordem semântica, como tal, o qual refere o vivo enquanto tal, o atual da linguagem"777. A nova unidade linguística com a qual se deve preocupar a fenomenologia já não diz respeito apenas à ordem dos signos mas à fala ou discurso, cuja unidade mínima é a frase. É ela que verdadeiramente significa ${ }^{778}$.

Quer dizer então: o valor da linguística estrutural para Ricoeur é semelhante àquele que o filósofo atribui à psicanálise ${ }^{779}$; tal como a hermenêutica da suspeita, o estruturalismo efetua uma crítica ao primado do sujeito e suas condições. A linguística redimensiona o conceito fenomenológico de significação, de tal modo que "uma fenomenologia renovada da significação não pode contentar-se em repetir as descrições da fala que não reconhecem o estatuto teórico da linguística e o primado da estrutura sobre o processo" 780 .

À fenomenologia hermenêutica da linguagem interessa pois desimplicar a partir da etapa semiótica a semântica na qual a linguagem sempre diz algo de alguma coisa e que é representada pelas suas frases. É preciso então, pensa Ricoeur, saber que "opor o signo

\footnotetext{
777 Ricoeur (1969), 255.

778 Ricoeur (1969), 247-248.

779 Cf. Ricoeur (1965).

780 Ricoeur (1969), 247-248.
} 
ao signo constitui a função semiológica; representar o real através do signo representa a função semântica; e a primeira está subordinada à segunda; ou se pretendemos, é em vista da função significante ou representativa que a linguagem é articulada". ${ }^{781}$ É necessário desimplicar pacientemente o nível de transcendência da linguagem, a sua referência, numa "luta taco a taco com os pressupostos da semiologia", e alguns linguistas convidam-nos justamente a isso, em ordem a poder compor o nível do sentido e depois o outro sentido da referência e o seu tipo de relação com o real.

A fenomenologia hermenêutica trabalha com o discurso e com o texto (da ação). É a ação sensata o seu grande escopo. Ora, esta não se deixa observar nem reduzir ao modelo explicativo causal das ciências da natureza; é um acontecer, uma possibilidade em aberto da natureza, um ser em ato que imediatamente deixa de ser, para pertencer ao passado, mas que fica pelo seu significado e pelas suas manifestações sociais. Uma fenomenologia da ação descobre nelas alguns traços semelhantes ao texto enquanto texto ${ }^{782}$ : nomeadamente o caráter significativo ou legível das suas conexões internas.

\section{II}

Com efeito, a estrutura noemática ou intencional da ação humana é justamente aquilo que perdura e se repercute depois do acontecimento-ação e do seu autor terem desaparecido, e é justamente esta intencionalidade que pode ser lida, atualizada ou preenchida em situações diferentes daquela em que se produziu a ação originária ${ }^{783}$. Aqui reside a origem do problema da transmissão e da interpretação. A ação, lembra-nos Ricoeur,

\footnotetext{
${ }^{781}$ Ricoeur (1969), 248.

782 Ricoeur (1986), 183.

783 Ricoeur (1986), 197.
} 
"é um fenómeno social, não apenas porque é a obra de vários agentes, de tal modo que o papel de cada um deles não se pode distinguir do papel dos outros, mas também porque os nossos atos nos escapam e têm efeitos que não tínhamos visado. Aparece aqui uma das significações da noção de 'inscrição' [...]. Uma ação deixa um 'rasto', põe a sua marca, quando contribui para a emergência de tais configurações que se tornam os documentos da ação humana."784

Toda a ação com sentido ultrapassa a sua situação inicial e abre-se pelo seu nexo ou encadeamento a novas leituras e apropriações. Nesta linha Ricoeur pergunta: "não será uma caraterística fundamental das grandes obras de cultura o facto de ultrapassarem as condições da sua produção social, do mesmo modo que um texto desenvolve novas referências e constitui novos mundos?"785

Será com o conceito de metáfora viva que Ricoeur, na sequência da via longa da sua fenomenologia hermenêutica, vai repensar a questão da suspensão fenomenológica do real, própria do texto da ação, alargando-a à função simbólica das grandes obras literárias. A referência da obra literária excede a simples designação ostensiva da realidade, mas não deixa de se dirigir

“para algures, mesmo para nenhuma parte; [...], porque designa o não-lugar em relação a toda a realidade, ela pode visar indiretamente esta realidade, segundo aquilo a que eu gostaria de chamar um novo 'efeito de referência' [...]. Este novo efeito de referência ou a nova referência do literário não é mais do que o poder da ficção de voltar a descrever a realidade." 786

\footnotetext{
784 Ricoeur (1986), 194.

785 Ricoeur (1986), 196.

786 Ricoeur (1986), 221.
} 
E o filósofo lembra-nos, a este propósito: a primeira forma com a qual tentamos compreender e esquematizar as peripécias do campo prático é justamente a ficção.

A estrutura de enredo da ficção permite uma ordenação da diversidade das práticas de vida pelas quais nos dispersamos. Mas atenção, uma poética da ação pede muito mais do que uma reconstrução descritiva. ${ }^{787}$ É assim que Ricoeur valoriza a épochè da referência ostensiva, feita pelo modelo de explicação do estruturalismo e adota o modelo explicativo destas ciências, em ordem a mediar a conceção tradicional de interpretação, meramente psicológica de textos e ações e a poder tratá-los de acordo com as regras elementares da linguística. Lembra-nos que:

"a função semiótica ou simbólica, que consiste em substituir os signos às coisas e em representar as coisas por meio de signos, parece ser mais do que uma superestrutura da vida social. Constitui o seu fundamento. Deveríamos dizer, de acordo com esta função generalizada do semiótico, não só que a função simbólica é social, mas que a realidade social é fundamentalmente simbólica"788.

Então o próprio processo da ficção característico da literatura, enquanto metáfora viva, exige o conhecimento dos sistemas semióticos e o seu modelo de explicação, tão diferente do modelo causal clássico, dado que tais sistemas se orientam pela procura da correlação interior entre os elementos constitutivos. A semântica profunda do texto descoberta pela semiótica é semelhante à da ação; a sua explicação, marcada pelas correlações internas, constitui então a mediação necessária para que qualquer apropriação do texto perca a sua tendência para uma

787 Ricoeur (1986), 223.

788 Ricoeur (1986), 209. 
identificação com uma interpretação psicológica. Neste sentido Ricoeur apropria-se do legado do estruturalismo e da sua noção de explicação para poder ultrapassar todo o psicologismo tradicional da interpretação dos textos e significações. No entanto o seu objetivo é exceder também os limites estreitos do sistema estrutural, pensando por meio dele e para além dele o sentido da nova referência e o alcance de uma nova compreensão. Renunciando a identificar a redução fenomenológica com a visão direta que, de um só golpe, faria brotar a atitude fenomenológica a partir da natural, o filósofo explora a via longa do desvio pelos signos, símbolos, textos e metáforas (vivas) e procura a redução entre as condições de possibilidade da relação significante que o homem estabelece com o mundo, por meio de uma imaginação regrada.

Conduzida deste modo por uma filosofia da linguagem, que enfrenta o desafio do estruturalismo e a dialética da compreensão e da explicação, a redução fenomenológica acabará por deixar de parecer uma operação fantástica no termo da qual a consciência seria um resto, um resíduo resultante da subtração do ser. Encaramos assim, lembra-nos Ricoeur, o nascimento da consciência no seio do mundo dos signos e a redução como o verdadeiro lugar da inovação semântica (metáfora viva) e ocasião de retorno a si de um sujeito a partir do seu outro. Isto é, assistimos ao advento de um si instruído pelo modo como os sistemas semânticos, simbólicos e narrativos reorganizam o mundo. Assistimos ainda pelo efeito catártico da interpretação dos signos privados e públicos, psíquicos e culturais em que se expõe e explicita o desejo de ser e o esforço para existir que sempre constitui o Dasein, à sua refiguração de si.

Com efeito, este tipo de interpretação que deixa de lado o psicologismo e o naturalismo, porque atravessou a prova da semiótica, é uma apropriação que expropria o eu do seu subjetivismo. Fá-lo na medida em que solicita o intérprete a participar no processo linguístico de suspensão da referência direta, dado que esta é a condição de possibilidade de uma referência desdobrada que só o leitor pode desimplicar: 
“Esta suspensão da referência é apenas a condição negativa de uma referência mais radical, mais indireta, construída sobre as ruínas da referência direta. Podemos chamar a esta referência indireta referência de segunda ordem, tendo em conta o primado da referência descritiva na linguagem ordinária e na ciência. Mas sob um outro ponto de vista, mais ontológico e menos epistemológico, a referência desdobrada constitui a referência primordial, na medida em que ela sugere, revela e retira do ocultamento as estruturas profundas da realidade às quais estamos ligados, enquanto mortais, nascidos neste mundo e chamados a habitá-lo por um tempo."789

A referência desdobrada, a metáfora - situada nomeadamente ao nível da lexis poética, cujo núcleo central é o muthos e não a palavra - é inseparável, segundo Ricoeur, da dimensão criadora de toda a representação feita por meio da linguagem. É esta a tese central de A Metáfora Viva: a metáfora não é apenas um desvio relativamente à linguagem corrente, é por esse mesmo desvio, o instrumento privilegiado da promoção de sentido que é, nomeadamente, feita pela mimêsis, de que já Aristóteles falava na Poética.

Quer dizer, o muthos poético, compreendido como mimese da ação, significa simultaneamente uma rotura e uma continuidade com o mundo em que vivemos. Então, a metáfora, outrora mera aventura da palavra (tropo) pode ser ligada, através da lexis, à tragédia ou poética. Esta, não o esqueçamos, era já definida por Aristóteles como "a imitação dos homens que agem". É para Ricoeur muito importante entender bem a proximidade entre o muthos do poema trágico e a lexis em que se inscreve a metáfora. O traço fundamental do muthos reside, lembra-nos, no seu caráter de ordem, de organização e de estruturação. Se aproximarmos estes três momentos de ordenação dos versos, de interpretação pela pa-

789 Ricoeur (1982). 
lavra e de manifestação pela linguagem ${ }^{790}$ veremos desenhar-se a função da lexis como exteriorização e explicitação interna do muthos. Assim,

"entre o muthos da tragédia e a sua lexis existe uma relação que podemos arriscar-nos a expressar como a de uma forma interior relativamente exterior. É então que a lexis, da qual a metáfora é uma parte, se articula no interior do poema trágico, no muthos e torna-se, por sua vez, parte da tragédia."791

E Ricoeur pergunta ainda: o que acontece à relação entre o muthos do poema trágico e a função representativa da mimese? O filósofo lembra-nos que de Platão a Aristóteles a mimese sofreu uma modificação notável, pois, enquanto em Platão se aplicava a todas as artes, aos discursos e às coisas naturais que são imitação dos modelos ideais, em Aristóteles nada disto acontece ${ }^{792}$. Em primeiro lugar a definição mais restrita surge no início do discurso científico e não no termo do uso dialético.

"Pois, se as palavras têm mais de um sentido, o seu uso na ciência só admite um. E é a divisão das ciências que define este uso normativo. Daqui resulta que apenas uma significação literal da mimese é admitida, aquela que restringe o seu uso ao quadro das ciências poéticas, distintas das ciências teóricas ou práticas. Só há mimêsis quando há um fazer."793

A Poética define aliás, de forma precisa, a imitação, como um processo criador, como o processo de construção de cada uma das seis partes

\footnotetext{
790 Ricoeur (1975), 53.

791 Ricoeur (1975), 53.

792 Ricoeur (1975), 54.

793 Ricoeur (1975), 54.
} 
constitutivas da tragédia, desde a intriga até ao espetáculo. Ricoeur retém desta nova estrutura lógica da imitação dois traços capazes de o ajudarem na sua construção de uma filosofia da metáfora. Um diz respeito ao papel do muthos na criação poética. É por meio dele que é feita a mimese, o que permite distinguir a mimese poética de toda a duplicata. O outro refere-se ao modo como surge, no próprio núcleo da mimese, uma tensão entre a submissão ao real e o trabalho criador da poesia. Então, o poeta é muito mais um artista, criador de fábulas, do que um criador de versos; é poeta enquanto imita as ações humanas. Quer isto dizer que na mimese aristotélica o movimento de referência é inseparável da dimensão criadora da fábula. Esta eleva-se ao universal da condição humana e capta os seus nexos lógicos de ordem verosímil. A mimêsis é poiesis e reciprocamente ${ }^{794}$, por meio do desvio do muthos e da sua concordância discordante.

Na tragédia, nomeadamente, retém Ricoeur de Aristóteles, a imitação das ações humanas é já uma imitação icónica, traço que é justamente a chave para entender a função da metáfora. ${ }^{795}$ A comédia, dizia Aristóteles, representa os homens inferiores, enquanto a tragédia quer apresentá-los magnificados. Então o muthos não é apenas uma ordenação das ações humanas de forma mais coerente, mas uma composição sobre-elevada. ${ }^{796}$ A rotura imposta pelo muthos é assim a condição da estruturação da ficção que permite à mimese restituir o humano não só segundo o que lhe é essencial, mas de modo mais nobre e elevado. É este traço, diz-nos Ricoeur que, ligado ao anterior nos conduz à metáfora. Assim,

"colocada sob o pano de fundo da mimêsis, a metáfora perde todo o caráter gratuito [...]. A subordinação da lexis ao muthos

\footnotetext{
794 Ricoeur (1975), 56.

795 Ricoeur (1975), 57.

796 Ricoeur (1975), 57.
} 
coloca já a metáfora ao serviço do 'dizer', do 'poematizar', que se exerce já não ao nível da palavra, mas do poema inteiro"797.

por sua vez, a subordinação do muthos à mimêsis dá ao procedimento de estilo uma visão global comparável à da persuasão em retórica. Encarada formalmente, enquanto desvio, a metáfora é apenas uma diferença no sentido; no entanto, referida à imitação das ações melhores, ela participa da dupla tensão característica da mimêsis: submissão à realidade $e$ invenção fabulosa; restituição e elevação.

Esta tensão dupla constitui justamente a função referencial da metáfora em poesia. ${ }^{798}$ A metáfora é considerada por Ricoeur como o instrumento privilegiado da promoção do sentido feita pela mimese. Para ela, a realidade continua a ser uma referência, sem no entanto nunca se transformar num constrangimento. É na composição da intriga que deve ser lida a referência à ação humana que é aqui a natureza imitada. E, segundo o filósofo, esta conceção de mimese, por meio de uma metáfora, revela as coisas em ato e pressupõe uma nova noção de natureza, muito diferente da substancialista tradicional. A frase constante de Aristóteles "a arte imita a natureza"799 tem justamente como função distinguir o poético do natural e é por isso que a referência à natureza não é nunca um constrangimento que se faça sentir na composição do poema. É a fábula, inventada e estruturada segundo as regras da gramatologia, que é imitação da ação. Ela consegue apresentar os homens como se estivessem agindo e todas as coisas como se estivessem em ato. Ela é metáfora viva, enquanto diz a existência viva ${ }^{800}$; é atividade ou processo criador que imita por meio da articulação discursiva de tipo narrativo.

\footnotetext{
797 Ricoeur (1975), 57

798 Ricoeur (1975), 57.

799 Apud, Ricoeur (1975), 59

800 Ricoeur (1975), 60.
} 
É à polissemia do agir - do mundo da praxis - que Ricoeur quer alargar a suspensão fenomenológica do objetivismo e substancialismo da natureza, considerada como facto; daí a importância do seu diálogo crítico com o estruturalismo e a forma como interpreta o modelo aristotélico da Poética. Nesta, Ricoeur valoriza sobretudo o nexo mimêsis-muthos- $k a-$ tharsis e a relação entre mimêsis e praxis, o que the vai permitir elevar o muthos aristotélico à categoria de meta-género que inclua também e para além do drama, a narrativa de ficção e a histórica. Enquanto o modelo trágico de Aristóteles distinguia, de forma clara, o género dramático do épico e do histórico, Ricoeur quer justamente explorar o parentesco que o muthos próprio da Poética instaura entre drama e narração. O seu intuito é poder afirmar que hoje não tem qualquer sentido limitar a narrativa a ações impossíveis de dramatizar teatralmente.

Com efeito, pensa o filósofo, os dois géneros literários partilham um mesmo espaço de referência, as ações humanas que re(a)presentam e almejam os dois o mesmo objetivo: uma depuração hermenêutica das emoções do espetador e do leitor. Assim, - na linha das suas meditações sobre o primado da significação sobre o dos factos, percurso que o levou a distanciar-se de Merleau-Ponty, e a dialogar com a Psicanálise, com o Estruturalismo e Aristóteles - procura o filósofo francês extrair da Poética o modelo de realização da intriga que possa aplicar-se a qualquer composição narrativa:

“a apropriação que eu proponho e que pratico consiste em elevar atividade configuradora, pivot do ternário da Poética, e indo para além dos constrangimentos referidos, ao nível de uma compreensão narrativa." 801

É claro que o filósofo se confronta com os embaraços deste seu projeto de alargamento que transforma o modelo saído da Poética de

801 Ricoeur (1992), 470. 
Aristóteles numa espécie de invariante ou de ideal-tipo da narrativa. Pergunta então:

"quais as condições a que se deve submeter esta inscrição do ternário aristotélico no campo da narratividade para que esta alcance o grau de generalidade que exige o meta-género narrativo?" 802

Três são as condições que Ricoeur vai estabelecer: a) em primeiro lugar o conceito de atividade configuradora deve ser elevado ao mais elevado nível de formalidade que seja compatível com a compreensão narrativa ${ }^{803}$ e deve constituir-se como paradigma da pretensão referencial das ficções. Chamo narrativa, diz-nos, neste contexto, exatamente ao que Aristóteles apelida de muthos, isto é à ordenação de factos ${ }^{804}$; b) em segundo lugar, o conceito de ficção deve ter o sentido ativo da invenção que suspende o curso da praxis efetiva, e permite o nascimento da poiesis, da literatura ou da literalidade. Deve, pois, corresponder à suspensão do real, condição de possibilidade para que surja o espaço da ficção; c) em terceiro lugar, há que agrupar os problemas da poética narrativa com os problemas do tempo. Aristóteles ignorava este problema, no entanto a ordem de começo, meio e fim própria da intriga era sempre marcada na Poética pela discordância concordante que, para poder ser seguida, leva tempo, logo só pode ser temporal. Mas, lembra ainda o filósofo, era preciso ter aberto o espaço duplo da ficção e da narrativa para que surgisse o projeto

"de um acasalamento de narratividade e temporalidade que transforme o narrativo em guardião do tempo e da ficção

802 Ricoeur (1992), 470.

803 Cf. Ricoeur (1992), 471.

804 Ricoeur (1983), 62. 
o instrumento de exploração segundo o modo do como se, os modos de temporalização que escapam à linearidade do tempo cronológico e dos quais a ficção se liberta mais facilmente do que a historiografia." 805

Este modelo narrativo de compreensão encontra a sua objetividade própria na narratologia, implicada neste alargamento ricoeuriano da configuração particular do muthos narrativo. Mas, enquanto o estruturalismo anula, como vimos, o sujeito e a referência ao real, Ricoeur quer ir mais além. Concebe o sujeito como atividade e passividade, isto é, como uma capacidade de passar a ato (que exige a mediação do outro para se realizar), que dá testemunho de si, e vê o real como dunamis e energeia na linha da sua reconstrução do referido par aristotélico ${ }^{806}$. Então, se só a suspensão do naturalismo e do objetivismo permite ver outras dimensões da realidade e o estruturalismo ajuda a realizá-las apesar do seu reducionismo, é preciso valorizá-lo e ao mesmo tempo ultrapassá-lo, atendendo à dimensão de katharsis do muthos.

A verdade do imaginário, diz-nos o filósofo, o poder de deteção ontológico da poesia,

“eis o que pela minha parte vejo na mimêsis de Aristóteles. É por meio dela que a lexis está enraizada e que os próprios desvios da metáfora pertencem ao grande empreendimento de dizer o que é. Mas a mimêsis não significa apenas que todo o discurso é do mundo. Ela não preserva apenas a função referencial do discurso poético. Enquanto mimêsis phuseôs, ela liga esta função referencial à revelação do real como ato." 807

\footnotetext{
805 Cf. Ricoeur (1992), 473.

806 Cf. Fiasse (2006), 97-102,

807 Ricoeur (1975), 61.
} 
Ricœur descobre ainda que a atividade de composição narrativa, tal como ele a trabalha, a partir da sua interpretação de Aristóteles, pressupõe três etapas fundamentais da mimêsis que é necessário clarificar, pois elas são absolutamente nucleares para a conceção da ideia de imitação criadora e da de crise instaurada pelo espaço da ficção. As três etapas em referência são a prefiguração ou mimêsis I, a configuração ou mimêsis II e a refiguração ou mimêsis III; elas têm como elo a praxis temporal e como elemento crítico o muthos. Neste sentido, o filósofo explicita, em Temps et récit I, a sua teoria das três mimêsis implicadas na tríade muthos- mimesis- catharsis de Aristóteles.

A mimesis I designa o conjunto potencialidades simbólicas do campo prático, 808 a pré-compreensão dos nexos lógicos da ação humana, sem a qual poeta nenhum poderia representar agentes que se tornam nobres ou vis. Por outras palavras: compor uma intriga exige que se identifique a estrutura profunda do agir (motivos, fins, agentes), o que seria impossível se não houvesse uma partilha dos pressupostos éticos e do próprio fundo simbólico e cultural da praxis da época. É porque o poeta é um ser da praxis, que ele encontra uma ordenação implícita do campo prático, uma primeira forma de intencionalidade narrativa deste, ou melhor, todo um conjunto de estruturas temporais ${ }^{809}$ e pressupostos estruturadores da interação que lhe permitem transgredir e inovar por meio da fábula ou intriga. ${ }^{810}$ Sem o enraizamento no seio de tais pressupostos narrativos, a intriga não faria sentido pois não evocaria qualquer familiaridade com a nossa experiência quotidiana.

A mimesis II, por sua vez, é o próprio ato de configuração narrativa, feito com base nos códigos narrativos internos ao discurso, ato que abre

808 Cf. Ricoeur (1975), 91.

809 Cf. Ricoeur (1975), 95.

810 Ricoeur (1975), 100: "On voit quel est dans sa richesse le sens de mimesis I : imiter ou représenter l'action, c'est d'abord pré- comprendre ce qu'il en est de l'agir humain: de sa sémantique, de sa symbolique, de sa temporalité." 
pela sua função de mediação e transgressão o mundo engrandecido da composição poética, a possibilidade de uma história e a capacidade que ela tem de ser seguida ${ }^{811}$. Ela institui, nas palavras de Ricoeur, a literalidade da obra literária e as suas regras. É justamente aqui que intervém todo o seu diálogo com o estruturalismo.

Por sua vez, se é verdade que a Poética de Aristóteles não manifesta explicitamente qualquer interesse pela receção da obra, Ricoeur descobre nela traços claros da mimesis III, argumentando da seguinte maneira: a poética fala de estruturação, isto é, de uma atividade orientada, que apenas termina e se realiza no prazer do espetador e do leitor. ${ }^{812}$ Além disso, o possível em poesia é persuasivo justamente devido ao efeito que produz sobre o espectador: uma purificação das paixões de piedade e terror. Então, o principal eixo de uma teoria da referência, a jusante da obra, passa pela relação entre poesia, praxis, cultura e apropriação. 813 O alcance referencial da narrativa reside justamente na conversão do imaginário humano que o caráter metafórico do texto realiza pelo modo como questiona o universo sedimentado das ideias admitidas.

Contrariando neste sentido os estruturalistas franceses, depois de apropriar e repensar a sua crítica da referência imediata, Ricœur defende uma hermenêutica que contemple a narrativa não apenas como uma estrutura reduzida às suas leis internas, mas como uma mediação, entre o campo real ou ético da praxis a montante (mimese I) e o campo da receção a jusante (mimese III). Com efeito, só construindo uma relação entre os três modos miméticos se pode constituir a ponte entre a vida, a ação, e a narrativa, e

"é (...) tarefa da hermenêutica reconstruir o conjunto das operações pelas quais uma obra se eleva acima do fundo

\footnotetext{
811 Cf. Ricoeur (1975), 104

812 Cf. Ricoeur (1975), 80.

813 Cf. Ricoeur (1975), 83.
} 
opaco do viver, do agir e do sofrer para ser dada por um autor a um leitor que a recebe e assim muda o seu agir." 814

Concluindo, a fenomenologia da perceção de Merleau-Ponty teve, segundo Ricoeur, ainda uma conceção de linguagem e de significação limitada. A fenomenologia hermenêutica da praxis, a que se dedica o nosso filósofo, descentra o sujeito dialogando com as ciências da linguagem e com a Psicanálise e leva muito a sério a produção do texto simbólico, metafórico e narrativo enquanto o verdadeiro núcleo de um alargamento do alcance da redução fenomenológica.

\section{Bibliografia}

FIASSE, Gaëlle (2006): L'autre et l'amitié chez Aristote et Paul Ricoeur, Paris - Louvain, Institut Supérieur de Philosophie de Louvain-la-Neuve.

MERLEAU-PONTY, Maurice (1945) : Phénoménologie de la perception. Paris, Gallimard. MERLEAU-PONTY, Maurice (1960): Signes. Paris, Gallimard.

RICOEUR, Paul - Oliveira, Carlos (1990): « De la volonté à l'acte. Entretien ». In: BOUCHINDHOMME, C - ROCHLITZ, R. (Eds.): Temps et récit en débat. Paris, Cerf.

RICOEUR, Paul (1960): Philosophie de la volonté. Finitude et culpabilité. I. L'homme faillible. Paris, Aubier.

RICOEUR, Paul (1960b): Philosophie de la volonté. Finitude et culpabilité. II. La symbolique du mal. Paris, Aubier.

RICOEUR, Paul (1965): De l 'interprétation. Essai sur Freud, Paris, Seuil.

RICOEUR, Paul (1969): Le conflit des interprétations. Essais d herméneutique. Paris, Seuil. RICOEUR, Paul (1975): La métaphore vive. Paris, Seuil.

RICOEUR, Paul (1982): "Imaginação e Metáfora". In:

http:/ / www.uc.pt/fluc/lif/publicacoes / textos_disponiveis_online RICOEUR, Paul (1983): Temps et récit, I. Paris, Seuil.

RICOEUR, Paul (1986): Du texte à l'action, Essais d'herméneutique II. Paris, Seuil. RICOEUR, Paul (1992): Lectures 2. La contrée des philosophes. Paris, Seuil.

814 Ricoeur (1983), 107. 
